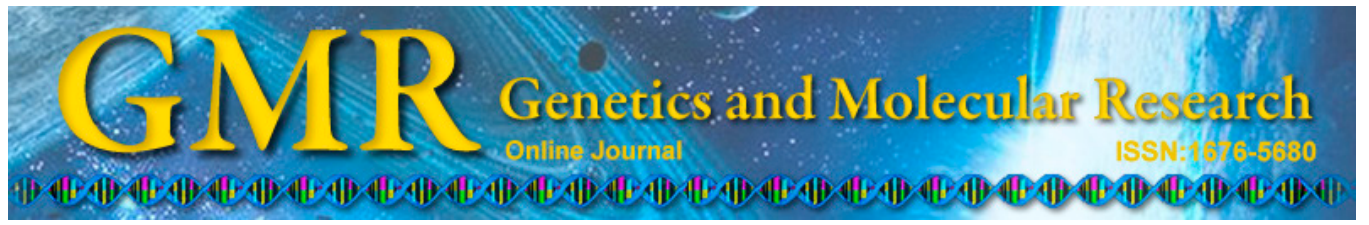

\title{
Complete mitochondrial genome of the Cyclemys dentata and phylogenetic analysis of the major family Geoemydidae
}

\author{
Y.N. Huang*, J. Li*, Q.Y. Jiang, X.S. Shen, X.Y. Yan, Y.B. Tang, \\ J. Huang, Y.F. Guo, G.Q. Lan and H.S. Jiang \\ College of Animal Science and Technology, Guangxi University, Nanning, China \\ *These authors contributed equally to this study. \\ Corresponding author: Q.Y. Jiang \\ E-mail: jiangqinyang@hotmail.com
}

Genet. Mol. Res. 14 (2): 3234-3243 (2015)

Received January 9, 2014

Accepted October 24, 2014

Published April 13, 2015

DOI http://dx.doi.org/10.4238/2015.April.13.2

\begin{abstract}
In the present study, the complete mitochondrial (mt) genome of Cyclemys dentata was determined using PCR reactions. The structural organization and gene order of $C$. dentata were equivalent to those of most other vertebrates. The mt genome was $16,489 \mathrm{bp}$ in length, has rich $\mathrm{A}+\mathrm{T}$ content, consisting of 13 protein-coding genes, 2 ribosomal RNA genes, 22 transfer RNA genes, and a control region (D-loop). All protein-coding genes started with ATG, many genes have complete stop codons, except $N D 2, C O X 3, N D 3$, and cyt-b genes had incomplete stop codons of T. The light-strand replication origin $\left(\mathrm{O}_{\mathrm{L}}\right)$ of $C$. dentata might fold into a stable stem-loop secondary structure, and its loop had $2 \mathrm{nt}$ less than that of the Cyclemys atripons $\mathrm{O}_{\mathrm{L}}$ sequence. The D-Loop of $C$. dentata contained a central domain (CD), 2 extended termination associated sequences (ETAS1, ETAS2) and 3 conserved sequence blocks (CSB1, CSB2, CSB3). The average length of 20 turtles' mt genomes was $16,692.5 \mathrm{bp}$, including $34.1 \% \mathrm{~A}$, $27.0 \% \mathrm{~T}, 26.0 \% \mathrm{C}$ and $12.9 \% \mathrm{G}$. The $\mathrm{C}$. dentata mitochondrial genome
\end{abstract}


mtDNA of C. dentata and phylogeny of family Geoemydidae.

could provide useful data for further studies on phylogenetics and conservation genetics of this species. The phylogenetic relationships of the family Geoemydidae were analyzed by maximum-likelihood (ML) and neighbor-joining (NJ) based on concatenated sequences of 13 protein-coding genes from 20 turtle species. The ML and NJ trees had homologous topologies. The results support the existing classification of the genera of Geoemydidae, that $C$. dentata was a sister species of C. atripons, Pyxidea nested in Cuora, and Chinemys was synonymous with Mauremys.

Keywords: Cyclemys dentata; Mitochondrial genome; Phylogenetic relationships

\section{INTRODUCTION}

In vertebrates, the mitochondrial $(\mathrm{mt})$ genome is a small double-stranded circular DNA, ranging in size from 15 to $20 \mathrm{~kb}$. The typical $\mathrm{mt}$ genome contains 38 components, including 13 protein-coding genes, 2 ribosomal RNA (rRNA) genes, 22 transfer RNA (tRNA) genes, and one control region (D-loop) (Boore, 1999). Because of its maternal inheritance, relative lack of recombination, and a higher rate of base substitution than most nuclear genes, the mt genome has been widely used to study taxonomy, phylogeny, genetic structure, and biological identification (Jiang et al., 2011). It has been employed as a marker in turtle science (Avise et al., 1992; Bowen et al., 1994; Shaffer et al., 1997; Kumazawa and Nishida 1999; Cao et al., 2000; van der Kuyl et al., 2002; Spinks et al., 2004; Krenz et al., 2005; Parham et al., 2006; Fritz et al., 2008; Stuart and Fritz, 2008; Zhang et al., 2008b; Wiens et al., 2010).

Turtles are one of the most instantly recognizable life forms on Earth; their characterization is dated back more than 200 million years ago (Krenz et al., 2005). With regard to the more recent diversity of turtles and tortoises throughout the world, there are 452 taxa comprising modern chelonians. Of these, 11 taxa have been extinct since $1500 \mathrm{AD}$; thus, currently, there are 441 taxa comprising living chelonians, including 322 species and 119 additional subspecies. The living chelonians are divided into 2 reciprocally monophyletic clades, including Pleurodira and Cryptodira (van Dijk et al., 2012). Geoemydidae, a Cryptodira family, is the world's largest turtle family and is comprised of 23 genera and approximately 73 species (Iverson, 1992; van Dijk et al., 2012).

The Asian Leaf Turtle, Cyclemys dentata (Gray 1831), belongs to the family Geoemydidae and is widely distributed from northern India to the Philippines; it can also be found in southern China (Stuart and Fritz, 2008). Although C. dentata is currently categorized as "Near Threatened" in the Red List by the International Union for the Conservation of Nature (IUCN, 2012), a large number of Asian leaf turtles are often caught and sold for the pet trade, food trade, or use in traditional Chinese medicine; thus, the number of wild turtles is declining. C. dentata is captive bred in China, which minimizes the impact on wild populations. However, the phylogeny of $C$. dentata is still poorly understood. Only the cytochrome b (cyt-b) gene of $C$. dentata mitochondrial DNA (mtDNA) and 3 nuclear DNA sequences (i.e., $C$-mos and Rag2 genes, and R35 intron) have been used to study the diversity of Cyclemys species (Fritz et al., 2008; Stuart and Fritz, 2008). Clearly, further study on C. dentata is necessary 
for species identification and conservation. In this paper, we sequenced and characterized the complete mt genome of $C$. dentata, and compared it to the mtDNA of other turtle species to acquire available molecular genetic information. We constructed molecular phylogenetic trees based on the mitochondrial genes to confirm relationships among the genera of the family Geoemydidae.

\section{MATERIAL AND METHODS}

\section{DNA sample}

The muscle sample from a 5-year-old, female $C$. dentata was obtained from the Zhong-Yi Turtle Farm of Qin-Zhou city in Guangxi Province, China. Total DNA was extracted from the muscle sample according to the method described by Sambrook and Russell (2001) and was used to sequence the complete mt genome.

\section{Polymerase chain reaction (PCR) and sequencing}

Sixteen pairs of primers were designed based on the complete mt genome of Cyclemys atripons (GenBank accession No. EF067858) and were used to amplify the mtDNA fragments of $C$. dentata via PCR, with each fragment sequence overlapping the next by $>50$ base pairs (bp). These primers are listed in Table 1. The PCR cycles were as follows: 5 min at $94^{\circ} \mathrm{C}$; followed by 35 cycles of $30 \mathrm{~s}$ at $94^{\circ} \mathrm{C}, 45 \mathrm{~s}$ at $55-56^{\circ} \mathrm{C}$, and $2 \mathrm{~min}$ at $72^{\circ} \mathrm{C}$; with a final extension at $72^{\circ} \mathrm{C}$ for $5 \mathrm{~min}$. PCR was carried out in a $50-\mu \mathrm{L}$ reaction mixture containing $100 \mathrm{ng}$ total DNA, 1X PCR buffer, $0.5 \mathrm{mM}$ dNTPmix, $1.5 \mathrm{mM} \mathrm{MgCl}_{2}, 1.0 \mu \mathrm{M}$ of each primer, and 2.0 U TaqDNA polymerase (TaKaRa, Dalian, China). The 16 PCR products were purified from 1\% agarose gel with the DNA Agarose Gel Extraction Kit (TaKaRa) and then sequenced directly by the primer walking method in an ABI3730 (Invitrogen Biotechnology Co. Ltd., USA). More than 3 copies of each fragment were sequenced to verify the reliability of the data.

Table 1. Sixteen PCR primers used in amplification of the complete mitochondrial genome of Cyclemys dentata.

\begin{tabular}{|c|c|c|c|c|}
\hline \multirow[t]{2}{*}{ No. } & \multicolumn{2}{|l|}{ Primers $\left(5^{\prime} \rightarrow 3^{\prime}\right)$} & \multirow{2}{*}{$\begin{array}{l}\text { Size } \\
\text { (bp) }\end{array}$} & \multirow{2}{*}{$\begin{array}{l}\mathrm{Tm} \\
\left({ }^{\circ} \mathrm{C}\right)\end{array}$} \\
\hline & forward & reverse & & \\
\hline 1 & CATGGCACTGAAGTTGCCAAG & TTTCGTCTTTCCCTTGCGGTA & 1209 & 56 \\
\hline 2 & CCCACCATAAACCAATTAAAAC & GTTTTATTTTACTCCGAGGTCG & 1121 & 55 \\
\hline 3 & TAAGACGAGAAGACCCTGTGGAAC & AGGAAGAATAAGGCGAATGGG & 1275 & 55 \\
\hline 4 & GCACCATTTGATTTAACCGAA & ATTATTCATCCTAGATGGGCGA & 1129 & 55 \\
\hline 5 & GGGGACTAAATCAAACCCAAC & TATACTGTTCATCCTGTGCCCG & 1287 & 55 \\
\hline 6 & GTACCCTTAATAATTGGAGCGC & TTCTTGGGTTTGTACATGGGC & 1278 & 56 \\
\hline 7 & TAGAATGATTACATGGCTGTCCACC & TTGCTTAGGGTTGGGAAGATGAT & 1219 & 56 \\
\hline 8 & CCAATATAAACCCATGAACCTG & TATACACCGTCAGCGATTGTG & 1265 & 55 \\
\hline 9 & CCAACCGAAACCAAACTATTC & CTATGGGTTAATGCGGTAGGT & 1176 & 55 \\
\hline 10 & GCTGGCATAGGCTTATCATT & TGGCTGAGAACCATCATAGG & 1150 & 55 \\
\hline 11 & CTAACACGAACAGAATGAGCA & TTCTGTTCGTCCTCGTCATC & 1160 & 55 \\
\hline 12 & GCCAACAACATACTTCAACTT & TTTCATACCAGGATAGGTCG & 1256 & 55 \\
\hline 13 & CCAACTCATTAGCCTACTTCA & TTGGCCTCATGGTAAGACAT & 1228 & 55 \\
\hline 14 & CATCGGTCGAGGACTTTACTAC & GGGTTGCTTATCTCTCGTGAT & 1278 & 55 \\
\hline 15 & TATGTATTATCGTGCATTCAT & GTGTCAGTTTAGTTGCTCTC & 720 & 55 \\
\hline 16 & GAGAGCAACTAAACTGACACA & AGTAAGGCTAGGACCAAATCT & 269 & 56 \\
\hline
\end{tabular}




\section{Data analysis}

Sequence data were analyzed with the DNASTAR Lasergene 7.0 software (DNASTAR Inc., USA). Overlapping contigs were compiled using SeqMan to assemble a continuous sequence. The locations of protein-coding genes, ribosomal RNA(rRNA), tRNA, and the control region were identified by tRNAscan-SE 1.21 (http://lowelab.ucsc. edu/tRNAscan-SE/), MegAlign program (DNASTAR), and a Blastn (http://www.ncbi.nim. nih.gov/BLAST/) comparison to other known turtle mt genomes. The complete mtDNA sequence of $C$. dentata was submitted to GenBank. Structure analysis of the control region was conducted in accordance with previously published methods (Sbisà et al., 1997; Zhang et al., 2008b).

Phylogenetic analyses of turtles were performed using MEGA version 5.2 (Tamura et al., 2011). The maximum composite likelihood (MCL) method was used to estimate evolutionary distances between DNA sequences. Nineteen mtDNA sequences of Geoemydidae were used to conduct the phylogenetic analyses, and Manouria impressa (Cryptodira; Testudinidae) mtDNA was used as the outgroup (Table 2). Thirteen protein-coding genes of these mtDNAs were aligned, and phylogenetic trees were constructed by maximum-likelihood (ML) and neighbor-joining (NJ) using MEGA 5.2. Each node of the tree was assessed with bootstrap percentages computed based on 1000 replications.

\begin{tabular}{|c|c|c|c|c|c|c|c|c|}
\hline \multirow[t]{2}{*}{ Family } & \multirow[t]{2}{*}{ Genus } & \multirow[t]{2}{*}{ Species } & \multirow[t]{2}{*}{ Accession No. } & \multicolumn{4}{|c|}{ Nucleotide proportion (\%) } & \multirow[t]{2}{*}{ mtDNA size (bp) } \\
\hline & & & & $\mathrm{T}$ & $\mathrm{C}$ & A & $\mathrm{G}$ & \\
\hline \multirow[t]{19}{*}{ Geoemydidae } & \multirow[t]{7}{*}{ Cuora } & Cuora amboinensis & FJ763736 & 26.7 & 26.4 & 33.8 & 13.1 & 16708 \\
\hline & & Cuora aurocapitata & AY874540 & 27.4 & 26.0 & 33.6 & 13.0 & 16890 \\
\hline & & Cuora bourreti & JN020145 & 26.8 & 26.2 & 33.9 & 13.1 & 16649 \\
\hline & & Cuora galbinifrons & EU809939 & 27.6 & 25.8 & 34.1 & 12.5 & 17244 \\
\hline & & Pyxidea mouhotii & DQ659152 & 27.3 & 25.8 & 34.0 & 12.8 & 16837 \\
\hline & & Cuora pani & GQ889364 & 27.4 & 25.9 & 33.7 & 13.0 & 16922 \\
\hline & & Cuora picturata & JF712890 & 26.9 & 26.1 & 34.0 & 13.0 & 16623 \\
\hline & \multirow[t]{2}{*}{ Cyclemys } & Cyclemys atripons & EF067858 & 27.2 & 25.4 & 34.4 & 13.0 & 16500 \\
\hline & & Cyclemys dentata & JX455823 & 27.2 & 25.4 & 34.3 & 13.1 & 16489 \\
\hline & Heosemys & Heosemys annandalii & JF742646 & 26.7 & 25.9 & 35.1 & 12.3 & 16604 \\
\hline & \multirow[t]{6}{*}{ Mauremys } & Mauremys japonica & GU938833 & 26.5 & 26.5 & 34.0 & 13.0 & 16443 \\
\hline & & Mauremys sinensis & FJ871126 & 26.2 & 26.8 & 33.8 & 13.2 & 16461 \\
\hline & & Mauremys mutica & DQ453753 & 26.5 & 26.5 & 33.8 & 13.2 & 16609 \\
\hline & & Chinemys reevesii & AY676201 & 26.6 & 26.4 & 34.0 & 12.9 & 16576 \\
\hline & & Mauremys reevesii & FJ469674 & 27.0 & 26.1 & 34.1 & 12.8 & 16781 \\
\hline & & Mauremys megalocephala & HM132059 & 27.2 & 25.9 & 34.1 & 12.8 & 16783 \\
\hline & Notochelys & Notochelys platynota & HQ853256 & 28.1 & 25.3 & 34.4 & 12.2 & 16981 \\
\hline & \multirow{2}{*}{ Sacalia } & Sacalia bealei & GU183364 & 26.9 & 25.9 & 34.2 & 13.1 & 16561 \\
\hline & & Sacalia quadriocellata & EF088646 & 26.9 & 25.9 & 34.3 & 12.9 & 16551 \\
\hline \multirow[t]{2}{*}{ Testudinidae } & \multirow[t]{2}{*}{ Manouria } & Manouria impressa & EF661586 & 26.3 & 26.4 & 34.2 & 13.1 & 16642 \\
\hline & & & Average: & 27.0 & 26.0 & 34.1 & 12.9 & 16692.5 \\
\hline
\end{tabular}

\section{RESULTS}

\section{Mitochondrial genome features}

The mitochondrial genome of $C$. dentata was initiallysequenced. It was $16,489 \mathrm{bp}$ 
in length and has been deposited into GenBank (accession No. JX455823). The structural organization (Table 3) and gene order (Figure 1) of the complete C. dentata mtDNA was identical to that of other typical vertebrates, with the $\mathrm{mt}$ genome containing the following: 13 protein-coding genes, 2 rRNAs, 22 tRNAs, and a control region (D-Loop). The overall base compositions of the $C$. dentata mtDNA were as follows: $\mathrm{A}=34.3, \mathrm{~T}=27.2, \mathrm{C}=25.4$, and $\mathrm{G}$ $=13.1 \%$. $\mathrm{A}+\mathrm{T}$ was observed more frequently than $\mathrm{G}+\mathrm{C}$, demonstrating the low $\mathrm{G}$ and high $\mathrm{A}+\mathrm{T}$ bias that is seen in other turtle species. The average base frequencies for the mtDNA of 20 turtle species were as follows: $\mathrm{A}=34.1, \mathrm{~T}=27.0, \mathrm{C}=26.0$, and $\mathrm{G}=12.9 \%$ (Table 2). This $\mathrm{A}+\mathrm{T}$ rich pattern reflects the typical sequence characteristic of the vertebrate mt genome. All protein-coding genes of the $C$. dentata mtDNA started with ATG. The ND2, COX3, ND3, and $c y t-b$ genes had incomplete stop codons of T; the COX1 and ND6 genes ended with AGG, the remaining protein-coding genes terminated with TAA (Table 3 ). The incomplete termination codon (i.e., T--) was common in animal mtDNAs and can be converted into a termination codon (i.e., TAA) after transcription (Boore, 2001).

Table 3. Structural organization of the Cyclemys dentata mitochondrial genome.

\begin{tabular}{|c|c|c|c|c|c|c|}
\hline \multirow[t]{2}{*}{ Gene/elements } & \multicolumn{2}{|c|}{ Position } & \multirow{2}{*}{$\begin{array}{l}\text { Size } \\
\text { (bp) }\end{array}$} & \multirow{2}{*}{$\begin{array}{l}\text { Strand } \\
\text { (sense) }\end{array}$} & \multicolumn{2}{|c|}{ Codon } \\
\hline & Origin & Stop & & & start & stop \\
\hline $\mathrm{tRNA}^{\mathrm{Phe}}$ & 1 & 70 & 70 & $\mathrm{H}$ & & \\
\hline $12 \mathrm{~S}$ rRNA & 71 & 1036 & 966 & $\mathrm{H}$ & & \\
\hline tRNA ${ }^{\text {Val }}$ & 1037 & 1106 & 70 & $\mathrm{H}$ & & \\
\hline 16S rRNA & 1107 & 2705 & 1599 & $\mathrm{H}$ & & \\
\hline tRNA $^{\text {Leu(UUR) }}$ & 2706 & 2781 & 76 & $\mathrm{H}$ & & \\
\hline ND1 & 2782 & 3750 & 969 & $\mathrm{H}$ & ATG & TAA \\
\hline tRNA $^{\text {Ile }}$ & 3753 & 3822 & 70 & $\mathrm{H}$ & & \\
\hline $\mathrm{tRNA}^{\mathrm{Gln}}$ & 3822 & 3892 & 71 & $\mathrm{~L}$ & & \\
\hline tRNA $^{\text {Met }}$ & 3892 & 3960 & 69 & $\mathrm{H}$ & & \\
\hline ND2 & 3961 & 5002 & 1042 & $\mathrm{H}$ & ATG & $\mathrm{T}--$ \\
\hline $\mathrm{tRNA}^{\mathrm{Trp}}$ & 5003 & 5077 & 75 & $\mathrm{H}$ & & \\
\hline tRNA $^{\text {Ala }}$ & 5079 & 5147 & 69 & $\mathrm{~L}$ & & \\
\hline tRNA $^{\text {Asn }}$ & 5149 & 5221 & 73 & $\mathrm{~L}$ & & \\
\hline $\mathrm{O}_{\mathrm{L}}$ & 5223 & 5250 & 28 & $\mathrm{~L}$ & & \\
\hline tRNA $^{\text {Cys }}$ & 5248 & 5313 & 66 & $\mathrm{~L}$ & & \\
\hline tRNA $^{\mathrm{Tyr}}$ & 5314 & 5384 & 71 & $\mathrm{~L}$ & & \\
\hline COX1 & 5386 & 6933 & 1548 & $\mathrm{H}$ & ATG & AGG \\
\hline tRNA $^{\text {Ser(UCN) }}$ & 6925 & 6995 & 71 & $\mathrm{~L}$ & & \\
\hline tRNA Asp & 6998 & 7067 & 70 & $\mathrm{H}$ & & \\
\hline $\mathrm{COX} 2$ & 7068 & 7754 & 687 & $\mathrm{H}$ & ATG & TAA \\
\hline tRNA $^{\text {Lys }}$ & 7756 & 7828 & 73 & $\mathrm{H}$ & & \\
\hline ATP8 & 7830 & 7997 & 168 & $\mathrm{H}$ & ATG & TAA \\
\hline ATP6 & 7988 & 8671 & 684 & $\mathrm{H}$ & ATG & TAA \\
\hline $\mathrm{COX} 3$ & 8671 & 9454 & 784 & $\mathrm{H}$ & ATG & $\mathrm{T}--$ \\
\hline tRNA $^{\text {Gly }}$ & 9455 & 9523 & 69 & $\mathrm{H}$ & & \\
\hline ND3 & 9524 & 9872 & 351 & $\mathrm{H}$ & ATG & $\mathrm{T}$ - - \\
\hline tRNA $^{\text {Arg }}$ & 9873 & 9942 & 70 & $\mathrm{H}$ & & \\
\hline ND4L & 9943 & 10242 & 300 & $\mathrm{H}$ & ATG & TAA \\
\hline ND4 & 10236 & 11612 & 1377 & $\mathrm{H}$ & ATG & TAA \\
\hline tRNA $^{\text {His }}$ & 11626 & 11695 & 70 & $\mathrm{H}$ & & \\
\hline tRNA $^{\mathrm{Ser}(\mathrm{AGY})}$ & 11696 & 11761 & 66 & $\mathrm{H}$ & & \\
\hline tRNA $^{\text {Leu(CUN) }}$ & 11761 & 11832 & 72 & $\mathrm{H}$ & & \\
\hline ND5 & 11833 & 13638 & 1806 & $\mathrm{H}$ & ATG & TAA \\
\hline ND6 & 13634 & 14158 & 525 & $\mathrm{~L}$ & ATG & AGG \\
\hline tRNA $^{\text {Glu }}$ & 14159 & 14226 & 68 & $\mathrm{~L}$ & & \\
\hline Cyt $b$ & 14231 & 15370 & 1150 & $\mathrm{H}$ & ATG & $\mathrm{T}$ - - \\
\hline tRNA $^{\mathrm{Thr}}$ & 15375 & 15446 & 72 & $\mathrm{H}$ & & \\
\hline $\mathrm{tRNA}^{\text {Pro }}$ & 15448 & 15516 & 69 & $\mathrm{~L}$ & & \\
\hline Control region & 15517 & 16489 & 973 & $\mathrm{H}$ & & \\
\hline
\end{tabular}




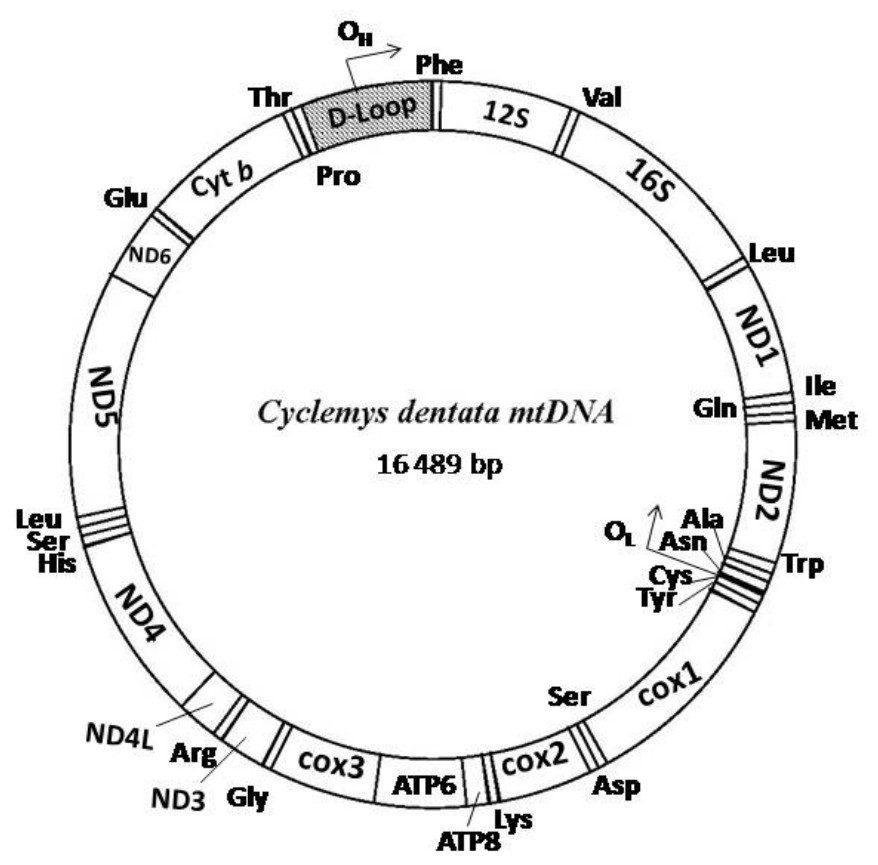

Figure 1. Order of the circular genes of the mitochondrial genome of Cyclemys dentata. 12S and 16S: 12S rRNA and 16S rRNA; ND1-6, ND4L: NADH dehydrogenase subunits 1-6, 4L; COX1-3: cytochrome oxidase subunits 1-3; Cyt b: cytochrome b; ATP6, 8: ATP synthase subunits 6, 8; D-loop: control region; each tRNA gene was identified by the 3-letter amino acid code; $\mathrm{O}_{\mathrm{H}}, \mathrm{O}_{\mathrm{L}}$ : the replication origin of the $\mathrm{H}$-strand and light strand replication.

\section{Noncoding sequences}

The lengths of the $C$. dentata $12 S$ and $16 S$ rRNA genes were 966 and $1599 \mathrm{bp}$, respectively, which were similar to other vertebrate species. Two genes were separated by the tRNA$\mathrm{Val}$ and positioned between the tRNA ${ }^{\text {Phe }}$ and tRNA ${ }^{\text {Leu (UUR) }}$ (Table 3). There were 22 tRNA genes in the $C$. dentata $\mathrm{mt}$ genome, ranging in size from 66 to $76 \mathrm{bp}$ (Table 3), that were interspersed between the protein-coding genes and rRNA, which are typical animal mtDNA genes that can be folded into the analogous cloverleaf secondary structure.

The light-strand replication origin $\left(\mathrm{O}_{\mathrm{L}}\right)$ of $C$. dentata was $28 \mathrm{bp}$ in length, which was positioned in the WANCY tRNA genes cluster and located between tRNA ${ }^{\text {Asn }}$ and tRNA ${ }^{\text {Cys }}$ (Table 3). The $\mathrm{O}_{\mathrm{L}}$ sequence of $C$. dentata might potentially fold into a stable stem-loop secondary structure, with a stem comprised of $10 \mathrm{bp}$ and a loop of 8 nucleotides (nt); this loop had 2 $\mathrm{nt}$ less than that of the Cyclemys atripons (C. atripons) $\mathrm{O}_{\mathrm{L}}$ sequence (Figure 2).

The length of the $C$. dentata mtDNA control region was $973 \mathrm{bp}, 68.35 \% \mathrm{~A}+\mathrm{T}$ rich, and flanked by the tRNA ${ }^{\text {Pro }}$ and tRNA ${ }^{\text {Phe }}$ genes (Table 3 ). Similar to other turtle species, 2 extended termination associated sequences, one central domain, and 3 conserved sequence blocks were identified in the $C$. dentata control region (Figure 3). There were AT enriched tandem repeats at the 3 ' end of this control region. The composition and number of these tandem units were variable for the different species, with 27 5'-TA-3' repeats in the $C$. dentata control region. 


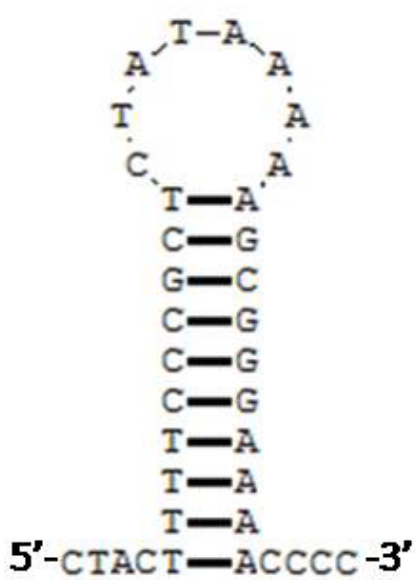

C dentota

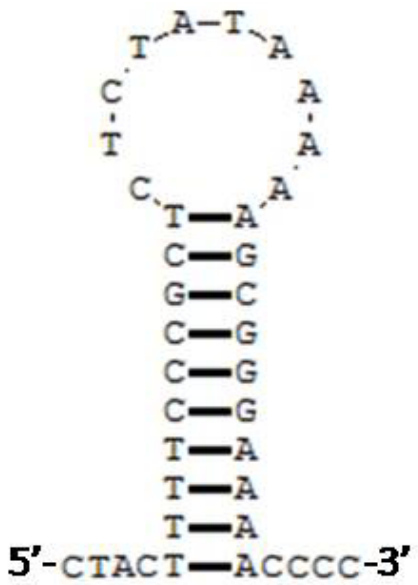

Cotripons

Figure 2. Secondary structures of the origins of the $\mathrm{O}_{\mathrm{L}}$ of 2 turtles.

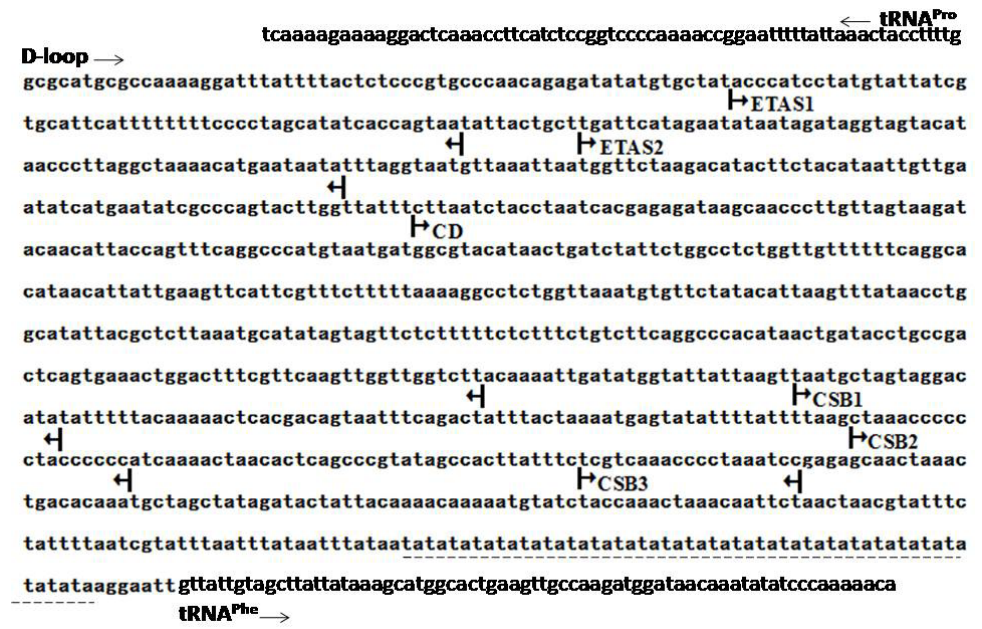

Figure 3. Structural elements of the control region (D-loop) of Cydemys dentata. ETAS1, 2: extended termination associated sequences 1, 2; CD: central domain; CSB1-3: conserved sequence blocks 1-3.

\section{Phylogenetic analysis}

The NJ and ML phylogenetic trees, which were constructed based on the mtDNA of the protein-coding genes from 20 turtle species, had similar topologies (Figure 4). According to clusters of the phylogenetic trees, $C$. dentata was a sister species to $C$. atripons ( $\mathrm{BP}=100 \%$ ), which initially clustered with the genus Sacalia, followed by clustering with the families Heosemys and Notochelys. Seven turtles of the family Cuora clustered with the monophyly of 6 turtles of the family Mauremys. Nineteen representative turtles of Geoemydidae were divided into 6 families. 

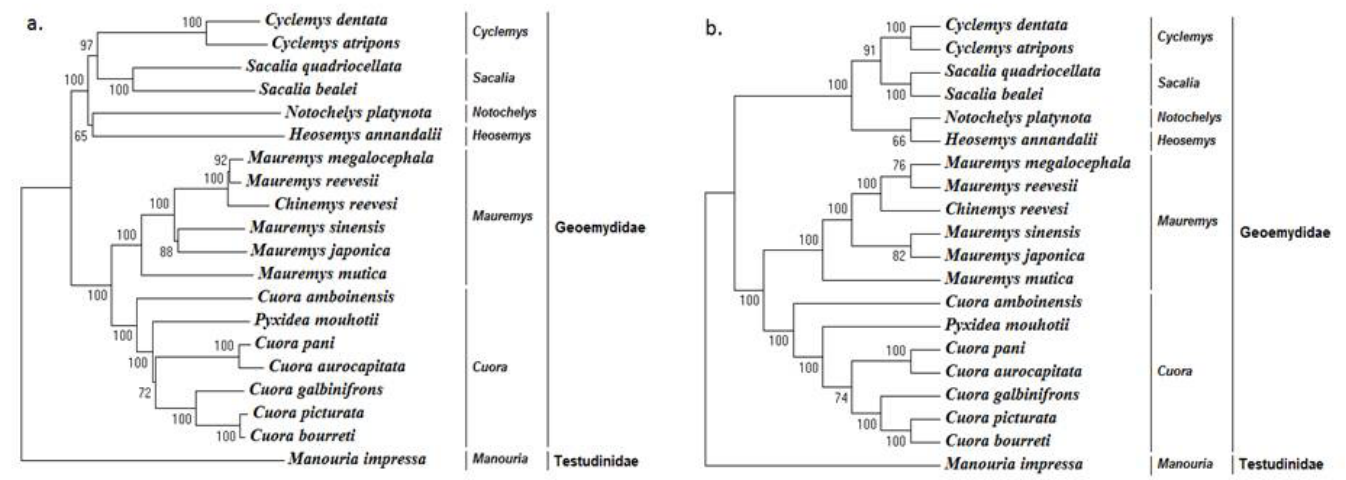

Figure 4. Phylogenetic trees constructed based on protein-coding genes from 20 turtles. Numbers above the branches indicate bootstrap proportions (BPs). Manouria impressa were used as outgroups.

\section{DISCUSSION}

The mitochondrial genome of vertebrates universally contained 37 genes and one control region, and the organization of the genes was almost analogous (Boore, 1999). The $\mathrm{mt}$ genome of $C$. dentata was 16,489 bp in length, and contained 37 genes and a control region. The organization and gene order of $C$. dentata mtDNA were similar to those of most other turtle species (Zhang et al., 2008a,b; Kumazawa and Nishida, 1999), except those of Platysternon megacephalum, whose complete mtDNA contained 2 control regions (Parham et al., 2006) and other distinctive features (Peng et al., 2006). We found that the size and nucleotides occupying the $C$. dentata mtDNA were the same as those of $C$. atripons. In addition, we did not find insertions in the ND3 gene; these extra nucleotides can be found in some turtle species (Mindell et al., 1998). The origin of the L-strand replication $\left(\mathrm{O}_{\mathrm{L}}\right)$ sequence nucleotides and secondary structure were conserved and may fold into a stable stem-loop structure. However, the base numbers of the stem or loop were among the different species. The stem and loop primarily contained 9 to 11 and 7 to $10 \mathrm{nt}$, respectively (Zhang et al., 2008b). The $\mathrm{O}_{\mathrm{L}}$ of $C$. dentata contained a 10-bp stem and 8-nt loop, which was different from that of C. atripons (i.e., 10-bp stem and 10-nt loop). The C. dentata control region was rich in $\mathrm{A}+\mathrm{T}$, and its $3^{\prime}$ end had 27 5'-TA-3' tandem repeats. The base composition of the repeat was different from that of other turtle species; there were 5'-A (AT) 3-3' repeats in C. atripons (EF067858) and 5'-ATATATC-3' units in C. reevesii (AY676201). The difference in the AT enriched tandem repeats may reflect species genetic diversity in turtles, and these repeats could be regarded as special genetic markers for use in genomic studies of turtles.

The Geoemydidae is the largest turtle family, contains rich species-level diversity, and is widely distributed throughout most of the planet's continents (Iverson et al., 1992; Spinks et al., 2004). However, the family Geoemydidae is known to be poor and in flux. In the present study, Cuora, Cyclemys, and Pyxidea were classified into the Cyclemys group, which was derived from a Heosemys-like ancestor, and the 4 genera were united into a Heosemys complex (Bramble, 1974). Afterwards, the Cuora were divided into Cuora and Cistoclemmys based on turtle morphology and 4 chromosomal characteristics (Hirayama, 1984; Yasukawa et al., 2001). However, Honda (2002) recommended synonymizing Cistoclemmys and Pyxidea with Cuora based on a phylogenetic analysis of rRNA sequences from mtDNA (Honda 
et al., 2002). A phylogenetic analysis of Cyclemys with the cyt-b gene of mtDNA and nuclear DNA data strongly support that Cyclemys contains 3 known species (i.e., C. pulchristriata, $C$. atripons, and C. oldhamii) and 2 undescribed species (Guicking et al., 2002). Spinks (2004) used $\mathrm{mt}$ and nuclear DNA data to study the phylogenetic relationships among 65 species and subspecies representing all 23 genera of Geoemydidae. The results suggest that the genus Mauremys is paraphyletic with Ocadia and Chinemys (Spinks et al., 2004). In the present study, we compiled the complete 13 protein-coding genes sequences of mtDNA to reconstruct the phylogenetic relationships among 19 the genera of Geoemydidae. The topologies were consistent between the NJ and ML trees. Our results supported the nesting of Pyxidea within Cuora and that Chinemys was synonymous with Mauremys.

Leaf turtles (genus Cyclemys, Geoemydidae) (Bell, 1834) were previously thought to belong to a genus that included only one or 2 species (Iverson, 1992); later, additional species were identified (Guicking et al., 2002; Fritz et al., 1997, 2008; Stuart and Fritz, 2008). According to morphology and preliminary nuclear DNA data, the Cyclemys could have 6 species, including 2 morphologically distinct groups, a yellow-bellied species group $(C$. dentata, $C$. atripons, and C. pulchristriata) and a dark-bellied species group (C. enigmatica, C. fusca, and C. gemeli) (Fritz et al., 2008). In our study, C. dentata and C. atripons were clustered together, indicating that they are sister species. Fritz et al. (2008) found that the mtDNA sequences of $C$. enigmatica did not differ from those of $C$. dentata but were highly distinct with regard to nuclear genomic markers, suggesting that the original $\mathrm{mt}$ genome of $C$. enigmatica was lost due to introgressive hybridization (Fritz et al., 2008). Hybridization among species might lead to a loss in biodiversity within the genus Cyclemys. On the other hand, the pet trade, food trade, and use in traditional Chinese medicine threaten wild populations of Cyclemys species. Thus, it is critical to conduct a comprehensive investigation on the genetic diversities of Cyclemys species and draft effective measures for the protection of wild turtles.

\section{CONCLUSION}

The structural organization and gene order of the C. dentata mitochondrial genome were similar to those of most other turtles; the complete mtDNA contained 37 genes and one control region. Based on the complete 13 protein-coding gene sequences, we reconstructed the phylogenetic relationships for 20 turtle species. The results support the existing classification of genera of Geoemydidae. We plan to conduct further studies on the genetic diversity of Cyclemys species in the near future.

\section{ACKNOWLEDGMENTS}

Research partially supported by the National Natural Science Foundation of China (\#81360135) and the Natural Science Foundation of Guangxi Province (\#2012GXNSFBA053041).

\section{REFERENCES}

Avise JC, Bowen BW, Lamb T, Meylan AB, et al. (1992). Mitochondrial DNA evolution at a turtle's pace: evidence for low genetic variability and reduced microevolutionary rate in the Testudines. Mol. Biol. Evol. 9: 457-473.

Boore JL (1999). Animal mitochondrial genomes. Nucleic Acids Res. 27: 1767-1780.

Boore JL (2001). Complete mitochondrial genome sequence of the polychaete annelid Platynereis dumerilii. Mol. Biol. Evol. 18: 1413-1416. 
Bowen BW, Kamezaki N, Limpus CJ, Hughes GR, et al. (1994). Global phylogeography of the loggerhead turtle (Caretta caretta) as indicated by mitochondrial DNA haplotypes. Evolution 48: 1820-1828.

Bramble DM (1974). Emydid shell kinesis: biomechanics and evolution. Copeia 1974: 707-727.

Cao Y, Sorenson MD, Kumazawa Y, Mindell DP, et al. (2000). Phylogenetic position of turtles among amniotes: evidence from mitochondrial and nuclear genes. Gene 259: 139-148.

Fritz U, Gaulke M, Lehr E (1997). Revision der südostasiatischen Dornschildkröten-Gattung Cyclemys Bell, 1834, mit Beschreibung einer neuen Art. Salamandra. 33: 183-212.

Fritz U, Guicking D, Auer M, Sommer RS, et al. (2008). Diversity of the Southeast Asian leaf turtle genus Cyclemys: how many leaves on its tree of life? Zool. Scr. 37: 367-390.

Guicking D, Fritz U, Wink M and Lehr E (2002). New data on the diversity of the Southeast Asian leaf turtle genus Cyclemys Bell, 1834. Molecular results (Reptilia: Testudines: Geoemydidae). Faunistische Abhandlungen des Staatlichen Museums für Tierkunde Dresden 23: 75-86.

Hirayama R (1984). Cladistic analysis of batagurine turtles (Batagurinae: Emydinae: Testudinoidea): a preliminary result. Studia Geologica Salmanticensia vol Especial 1. 1: 141-157.

Honda M, Yasukawa Y, Hirayama R and Ota H (2002). Phylogenetic relationships of the Asian box turtles of the genus Cuora sensu lato (Reptilia: Bataguridae) inferred from mitochondrial DNA sequences. Zool. Sci. 19: 1305-1312.

IUCN - International Union for the Conservation of Nature (2012). Red List of Threatened Species Version 2012. Available at [http://www.iucnredlist.org.search].

Iverson JB (1992). A revised checklist with distribution maps of the turtles of the world. Green Nature Books, Richmond.

Jiang Q, Wei Y, Huang Y, Jiang H, et al. (2011). The complete mitochondrial genome and phylogenetic analysis of the Debao pony (Equus caballus). Mol. Biol. Rep. 38: 593-599.

Krenz JG, Naylor GJ, Shaffer HB and Janzen FJ (2005). Molecular phylogenetics and evolution of turtles. Mol. Phylogenet. Evol. 37: 178-191.

Kumazawa Y and Nishida M (1999). Complete mitochondrial DNA sequences of the green turtle and blue-tailed mole skink: statistical evidence for archosaurian affinity of turtles. Mol. Biol. Evol. 16: 784-792.

Mindell DP, Sorenson MD, Dimcheff DE (1998). An extra nucleotide is not translated in mitochondrial ND3 of some birds and turtles. Mol. Biol. Evol. 15: 1568-1571.

Parham JF, Feldman CR and Boore JL (2006). The complete mitochondrial genome of the enigmatic bigheaded turtle (Platysternon): description of unusual genomic features and the reconciliation of phylogenetic hypotheses based on mitochondrial and nuclear DNA. BMC Evol. Biol. 6: 1-11.

Peng QL, Nie LW and Pu YG (2006). Complete mitochondrial genome of Chinese big-headed turtle, Platysternon megacephalum, with a novel gene organization in vertebrate mtDNA. Gene 280: 14-20.

Sambrook J and Russell DW (2001). Molecular cloning: a laboratory manual. Cold Spring Harbor Press, New York.

Sbisà E, Tanzariello F, Reyes A, Pesole G, et al. (1997). Mammalian mitochondrial D-loop region structural analysis: identification of new conserved sequences and their functional and evolutionary implications. Gene 205: 125-140.

Shaffer HB, Meylan P and McKnight ML (1997). Tests of turtle phylogeny: molecular, morphological, and paleontological approaches. Syst. Biol. 46: 235-268.

Spinks PQ, Shaffer HB, Iverson JB and McCord WP (2004). Phylogenetic hypotheses for the turtle family Geoemydidae. Mol. Phylogenet. Evol. 32: 164-182.

Stuart BL and Fritz U (2008). Historical DNA from museum type specimens clarifies diversity of Asian leaf turtles (Cyclemys). Biol. J. Linn. Soc. 94: 131-141.

Tamura K, Peterson D, Peterson N, Stecher G, et al. (2011). MEGA5: molecular evolutionary genetics analysis using maximum likelihood, evolutionary distance, and maximum parsimony methods. Mol. Biol. Evol. 28: 2731-2739.

van der Kuyl AC, Ph Ballasina DL, Dekker JT, Maas J, et al. (2002). Phylogenetic relationships among the species of the genus Testudo (Testudines: Testudinidae) inferred from mitochondrial 12S rRNA gene sequences. Mol. Phylogenet. Evol. 22: 174-183.

van Dijk PP, Iverson JB, Shaffer HB, Bour R, et al. (2012). Turtles of the world, 2012 update: annotated checklist of taxonomy, synonymy, distribution, and conservation status. Conserv. Biol. Freshwater Turtles and Tortoises 5: 243-328.

Wiens JJ, Kuczynski CA and Stephens PR (2010). Discordant mitochondrial and nuclear gene phylogenies in emydid turtles: implications for speciation and conservation. Biol. J. Linn. Soc. 99: 445-461.

Yasukawa Y, Hirayama R and Hikida T (2001). Phylogenetic relationships of geoemydine turtles (Reptilia: Bataguridae). Curr. Herpetol. 20: 105-133.

Zhang L, Nie LW, Cao C and Zhang Y (2008a). The complete mitochondrial genome of the Keeled box turtle Pyxidea mouhotii and phylogenetic analysis of major turtle groups. J. Genet. Genomics. 35: 33-40.

Zhang L, Nie LW, Zhang Y, Rui JL, et al. (2008b). Complete sequence and organization of the mitochondrial genome of Cyclemys atripons (Testudines, Geoemydidae). Genet. Mol. Biol. 31: 783-788. 